\title{
Characterization of Air-Based Photovoltaic Thermal Panels with Bifacial Solar Cells
}

\author{
P. Ooshaksaraei, ${ }^{1,2}$ K. Sopian, ${ }^{1}$ R. Zulkifli, ${ }^{2}$ and Saleem H. Zaidi ${ }^{1}$ \\ ${ }^{1}$ Solar Energy Research Institute, Universiti Kebangsaan Malaysia (UKM), Bangi, 43600 Selangor, Malaysia \\ ${ }^{2}$ Department of Mechanical and Materials Engineering, Faculty of Engineering and Built Environment, \\ Universiti Kebangsaan Malaysia (UKM), Bangi, 43600 Selangor, Malaysia \\ Correspondence should be addressed to P. Ooshaksaraei; poorya@eng.ukm.my
}

Received 15 July 2013; Accepted 5 November 2013

Academic Editor: Vincenzo Augugliaro

Copyright (C) 2013 P. Ooshaksaraei et al. This is an open access article distributed under the Creative Commons Attribution License, which permits unrestricted use, distribution, and reproduction in any medium, provided the original work is properly cited.

\begin{abstract}
Photovoltaic (PV) panels account for a majority of the cost of photovoltaic thermal (PVT) panels. Bifacial silicon solar panels are attractive for PVT panels because of their potential to enhance electrical power generation from the same silicon wafer compared with conventional monofacial solar panels. This paper examines the performance of air-based bifacial PVT panels with regard to the first and second laws of thermodynamics. Four air-based bifacial PVT panels were designed. The maximum efficiencies of $45 \%$ to 63\% were observed for the double-path-parallel bifacial PVT panel based on the first law of thermodynamics. Single-path bifacial PVT panel represents the highest exergy efficiency (10\%). Double-path-parallel bifacial PVT panel is the second preferred design as it generates up to $20 \%$ additional total energy compared with the single-path panel. However, the daily average exergy efficiency of a double-path-parallel panel is $0.35 \%$ lower than that of a single-path panel.
\end{abstract}

\section{Introduction}

Solar energy is one of the most environment friendly sources of renewable energies that can be utilized in thermal and electrical applications. Photovoltaic thermal (PVT) collectors are especially designed to generate both electrical and thermal energies simultaneously. Solar air-heater panels, also referred to as hybrid panels, have been widely studied in the last decade and have been found to be strongly suitable for applications that require both electrical and thermal energies, such as space heating and drying.

A PVT panel generally consists of PV cells, an absorber plate, and a heat removal system. In a bifacial PVT panel, monofacial PV cells are replaced by bifacial PV cells, and the absorber plate is replaced by a reflector. Reducing the number of solar cells will significantly reduce the cost of the module, given that solar cells are expensive [1].

1.1. Bifacial Solar Cells. Recent studies on PV solar cells have developed the bifacial PV solar cell [2]. The bifacial solar cell, in contrast with monofacial solar cell, has the capability to absorb solar radiation from the rear surface as well as the front surface, simultaneously. Figure 1 compares the mechanism of solar radiation absorption between a bifacial solar cell and a monofacial solar cell.

Solar radiation absorption by the rear surface increases electrical energy generation [3]. A bifacial PV panel generates $30 \%$ to $90 \%$ additional electrical energy compared with a monofacial PV panel at optimum adjustment $[4,5]$. Industrialized bifacial solar cells have front and rear efficiencies of $16.6 \%$ and $12.8 \%$, respectively. Assuming identical microstructures on the front and rear surfaces of solar cells, the lower energy conversion efficiency of the rear surface compared with the front surface may be due to different optical responses of the front and rear surfaces $[6,7]$. Electrical energy generated by the rear surface of bifacial solar cells strongly depends on reflection performance of the reflector [8].

1.2. Reflector. Bifacial solar cells increase electrical efficiency of flat-plate PV panels at negligible cost increase [9]. Additional electrical energy generated by the rear surface of bifacial panels strongly depends on reflection properties and 


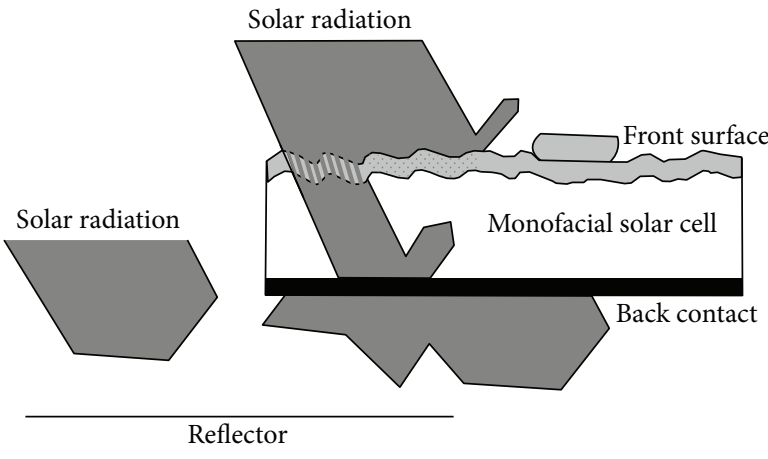

(a)

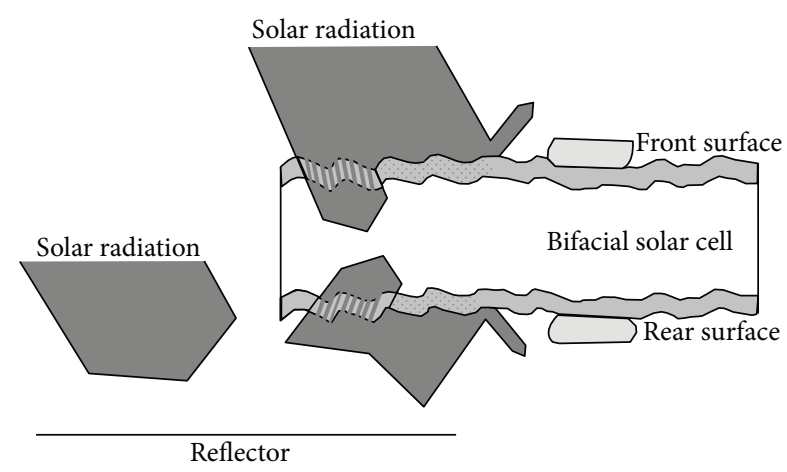

(b)

FIGURE 1: Radiation absorptions of monofacial and bifacial PV solar cells.

installation attitude of the reflector. Three key parameters have significant effects on panel performance: panel slope, reflector slope, and reflection efficiency. However, bifacial solar panels are effective without a reflector in certain applications [10-14]. In general, solar panels are classified either as one-sun (1X) panel or concentrator panel (multi$\mathrm{X}$ ). For bifacial panels, the definition of $1 \mathrm{X}$ panel and multi$\mathrm{X}$ panel may overlap. The front surface of a bifacial cell receives $1 \mathrm{X}$ solar radiation, whereas the rear surface may receive additional $1 \mathrm{X}$ beam radiation [15]. Reflection property of the reflector depends on surface roughness and color. A wide range of reflectors including diffuse, mirror, and semitransparent have been studied $[1,10,11,16]$. Uematsu [1] developed a flat plate bifacial panel by adding a static Vgroove concentrator to provide 1X solar radiation on the rear surface of the bifacial cell, which resulted in $85.6 \%$ power enhancement.

Intensity of solar radiation on the rear surface affects the power generated by a bifacial PV panel [8]. Moehlecke et al. [5] studied the reflection properties of painted reflectors placed beneath the bifacial solar cells. They observed up to $25 \%$ enhancement in solar absorption, compared with conventional monofacial panels. White-colored reflector is the optimum painted reflector with $75 \%$ average reflectance. Yellow is the second best color for reflectors followed by orange, red, green, blue, brown, purple, grey, dark blue, and dark green colors, which give $61 \%$ to $32 \%$ reflection [5].

1.3. Residential Applications of Bifacial Solar Cells. Buildingintegrated applications of monofacial PV and PVT panels have been widely studied, whereas the performance of building-integrated bifacial solar panels has not. Bifacial PV panels could be integrated into residential and commercial buildings as window-integrated, wall-integrated, or parking lot-integrated panels [9].

Bifacial solar cells partially cover the panel area. In wallintegrated application, the panel is installed with an offset distance from the wall. Front surface of bifacial solar cells absorb a portion of solar radiation, whereas a portion of solar radiation penetrates through transparent vacant space between cells; the wall reflects light back to the rear surface of bifacial cells [16].

Window-integrated bifacial PV panels produce electrical energy while permitting penetration of faint solar radiation into the interior area for lighting of residential or commercial buildings $[9,17]$. Packing factor of solar panel has significant impact on the amount of solar radiation that penetrates the PV module [18]. Space heating and drying applications could also be considered depending on the climate of the installation site.

1.4. Air-Based PVT Panel. Air-based PVT collectors are useful for both industrial and residential applications, such as drying and space heating. Air-based panel designs are classified according to the number or glazing and air-path. Single-glazing double-path (monofacial) panels have higher electrical and thermal efficiencies compared with single-path panel types [19]. In an air-based PVT panel, PV cells are placed at the top of the absorber plate and absorb a portion of solar radiation that reaches the front surface. The remaining portion of solar radiation penetrates the PV cells and reaches the absorber plate where it is converted into thermal energy.

Substituting monofacial PV cells with bifacial PV cells has led to the development of bifacial PVT panels. A bifacial PVT panel equipped with aluminum reflector generates $40 \%$ additional electrical and thermal energies [20].

Most of the existing PVT panel designs are inappropriate for bifacial solar cells because the absorber plate covers the rear surface of bifacial solar cells [21-24]. Absence of solar radiation on the rear surface of bifacial solar cells misses the benefit of dual surface solar radiation absorption of bifacial solar cells. Panel modification is essential; the absorber plate should be substituted by a reflector to reflect back solar radiation to the rear surface of bifacial solar cells.

The current research aims to develop new designs of air-based PVT panels based on bifacial solar cells and to evaluate the performance of the panel with regard to the first and second laws of thermodynamics. This paper represents steady-state simulation and daily simulation based on the climate of Malaysia. 


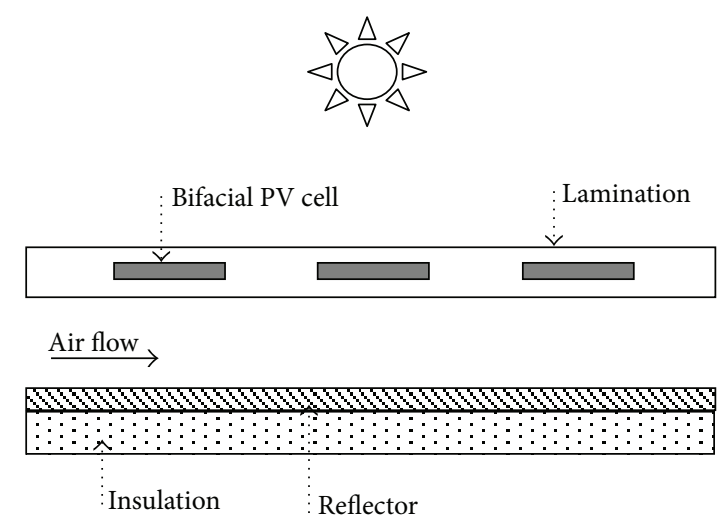

(a)
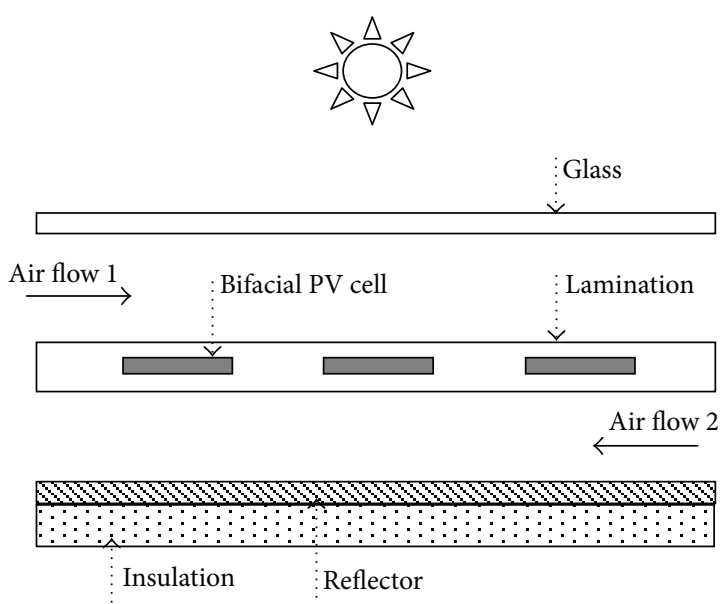

(c)

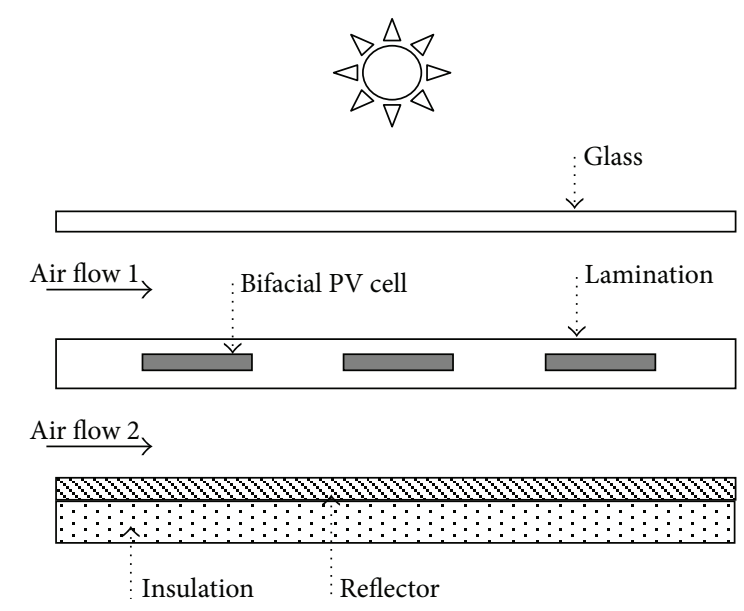

(b)
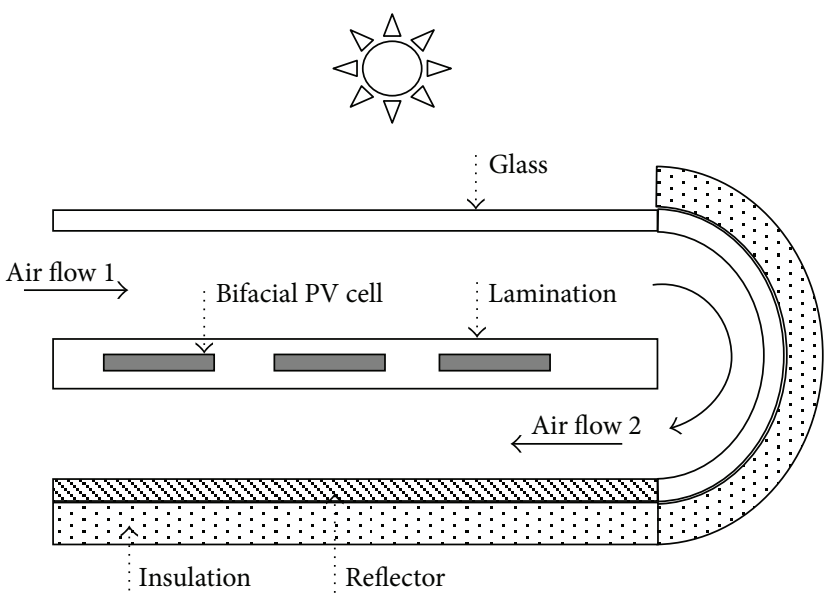

(d)

Figure 2: Cross-section view of bifacial PVT panel: (a) Model 1; (b) Model 2; (c) Model 3; and (d) Model 4.

\section{Mathematical Modeling}

Electrical and thermal performances of PVT panel strongly depend on cell temperature, air flow rate, and packing factor of the solar panel. Energy balance method and exergy method are the two most well-known methods for performance evaluation of PVT panels. The former (energy balance method) is based on the first law of thermodynamics, whereas the latter (exergy method) is based on the second law of thermodynamics.

2.1. PVT Panel Design. Varieties of air-based PVT panels have been widely studied in the last decade. Most PVT panel designs are incorporated with an opaque absorber plate on which PV cells are pasted. A few monofacial PV and PVT panel designs have the potential to be developed into a bifacial PVT panel $[25,26]$. Kamthania et al. [25] proposed and tested PV cells installed with a separation from the absorber plate and consequently found lower PV cell temperature and additional electrical energy generation. This design has the potential to be developed into a bifacial PVT solar panel.
In a bifacial PVT panel, the absorber plate should be substituted by an appropriate reflector installed beneath the bifacial PV cell to provide solar radiation on the rear surface of bifacial solar cells. The reflector is the key component of a bifacial PV panel. Both mirror-type and diffuse-type reflectors are suitable for bifacial panel design. Figure 2 represents four air-based bifacial PVT panels developed based on the existing monofacial PVT panel designs and the requirements of bifacial solar cells.

Configurations of four bifacial PVT panels are described as follows.

Model 1. Single-path, air-based bifacial PVT panel with a reflector placed beneath the PV lamination. Air flows between the lamination and the reflector (Figure 2(a)).

Model 2. Double-path, air-based PVT panel with additional layer of glazing above the PV lamination. Two parallel air streams exist. One air channel is above the PV lamination, and the other is beneath the lamination (Figure 2(b)). The two channels have similar geometries. Each channel carries 50\% of flow rate. 
Model 3. This model has a similar configuration to Model 2 , except that air in the lower channel flows in the direction opposite the upper channel (Figure 2(c)).

Model 4. This panel was developed based on Model 3. The upper and lower channels are in a series. Air flows above the PV lamination and flows back through the channel beneath the lamination (Figure 2(d)).

2.2. Energy Balance Method. All four models were simulated based on the first law of thermodynamics. The following assumptions were made.

(i) Both surfaces of the PV cell have the same electrical efficiencies.

(ii) The reflector has 70\% reflection efficiency.

(iii) Natural convection is suppressed inside the panel.

(iv) The only temperature gradient is along the panel.

(v) Thermal losses through insulation are negligible.

(vi) Ambient airspeed is equal to $1 \mathrm{~m} \mathrm{~s}^{-1}$.

Energy balance equations were developed and solved for all models. Output energy of the PVT panel consists of electrical and thermal parts, and efficiency of the panel is a combination of thermal and electrical efficiencies.

2.2.1. Heat Transfer Coefficients. Free convection heat transfer coefficients in ambient condition can be obtained from Duffie and Beckman [27]:

$$
h_{c}=2.8+u_{\text {Air }}
$$

where $u_{\text {Air }}$ is the air velocity over the panel, which was assumed to be $1 \mathrm{~m} \mathrm{~s}^{-1}$.

Internal forced convection heat transfer coefficients is defined as [28]

$$
h_{c}=\frac{K_{\mathrm{Air}}}{D_{H}} N u \text {, }
$$

where $h_{c}$ can be determined from Tan and Charters [29], which has been used by Shahsavar and Ameri [30]:

$$
h_{c}=0.0182 \operatorname{Re}^{0.8} \operatorname{Pr}^{0.4}\left[1+S^{\prime} \frac{D_{H}}{L}\right]
$$

where

$$
\begin{gathered}
S^{\prime}=14.3 \log \left(\frac{L}{D_{H}}\right)-7.9, \quad \text { for } 0<\left(\frac{L}{D_{H}}\right) \leq 60 \\
=17.5, \quad \text { for } 60<\left(\frac{L}{D_{H}}\right) \\
\operatorname{Re}=\frac{\rho u D}{\mu} \\
\operatorname{Pr}=0.7 .
\end{gathered}
$$

2.2.2. Evaluation of Performance. The total efficiency of the PVT panel is a function of electrical and thermal efficacies.

Both surfaces of the bifacial PV cell contribute to electrical energy generation, where the total electrical energy generated by bifacial PV cell is defined as follows:

$$
\mathrm{El}_{\mathrm{PV}}=\mathrm{El}_{\mathrm{PV}_{\text {front }}}+\mathrm{El}_{\mathrm{PV}_{\text {rear }}} \text {. }
$$

The actual electrical efficiency of the PV cell varies according to its temperature as [31]

$$
\eta_{\mathrm{PV}_{\text {front }}}=\eta_{\mathrm{PV}_{\text {rear }}}=\eta_{\text {ref }}\left\lfloor 1-\Phi_{\text {ref }}\left(T_{\text {Cell }}-T_{\text {ref }}\right)\right\rfloor,
$$

where $T_{\text {ref }}=25^{\circ} \mathrm{C}, \Phi_{\text {ref }}=1 /\left(T_{\mathrm{PV}}-T_{\text {ref }}\right)$, and $\eta_{\text {ref }}$ is the electrical efficiency of the panel at reference temperature $[19,32]$.

The thermal efficiency of a PVT panel is defined as the ratio of thermal energy transferred to working fluid(s) over total solar radiation reaching the collector area:

$$
\eta_{\mathrm{Th}}=\frac{\dot{m} C_{p}\left(T_{o}-T_{i}\right)}{S \times A} .
$$

Electrical energy has a higher value compared with thermal energy, which should be considered in calculating total efficiency [30]. The total energy efficiency of PVT panel is defined as

$$
\eta_{\text {Total }}=\eta_{\mathrm{Th}}+\frac{\eta_{\mathrm{El}}}{\eta_{\text {Power Plant }}}
$$

where $\eta_{\text {Power Plant }}=0.38$ is the efficiency of conventional power plant [33].

2.3. Exergy Analysis Method. Aforementioned studies evaluated the panels based on the first law of thermodynamics. However, exergy method evaluates panels based on the second law of thermodynamics. In exergy method, environment temperature is the reference temperature in calculating the theoretical maximum work done by the system in order to reach equilibrium with the reference environment [34].

Increasing the number of glazing is an advantage in PVT panel. Glazing reduces thermal losses and increases thermal efficiency, which is an advantage according to the first law of thermodynamics. However, solar radiation reflected back by the cover glass reduces solar radiation to solar cells, thereby decreasing electrical energy generation. Electrical energy has a higher value compared with thermal energy according to the first law of thermodynamics [35].

In accordance with the second law of thermodynamics, high-value electrical energy loss from reflected light caused by additional glazing should be compared with thermal energy saved from additional glazing.

In PVT panels, the maximum output exergy is observed at an inlet fluid temperature of $35^{\circ} \mathrm{C}$, whereas the maximum output energy is observed at an inlet fluid temperature of $31^{\circ} \mathrm{C}$ [36]. Energy and exergy efficiency rates of PVT panel vary indifferent designs. Table 1 presents energy and exergy efficiencies observed in previous studies.

The total output exergy of the PVT panel is higher than that of PV panel, and the thermal energy output of a PVT 


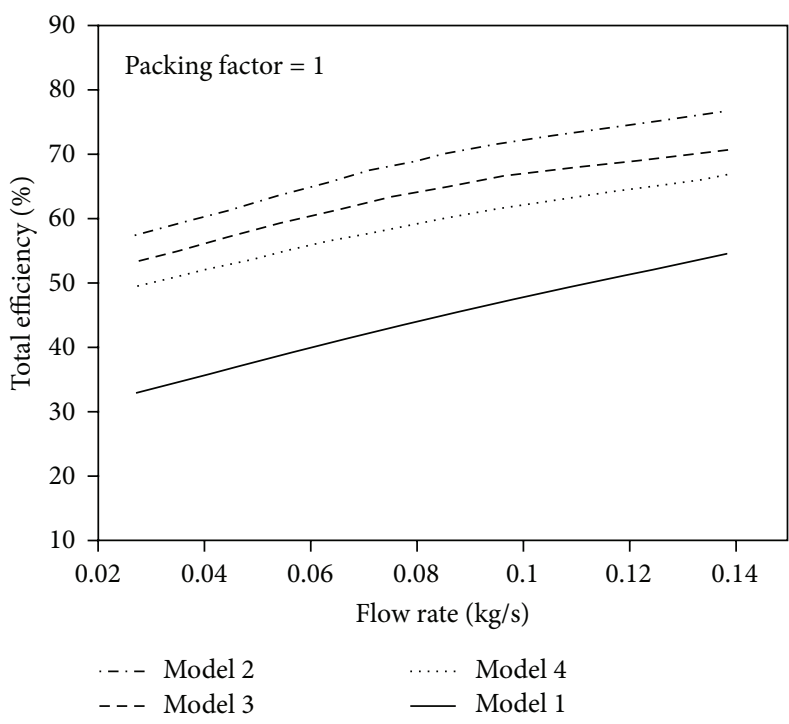

(a)

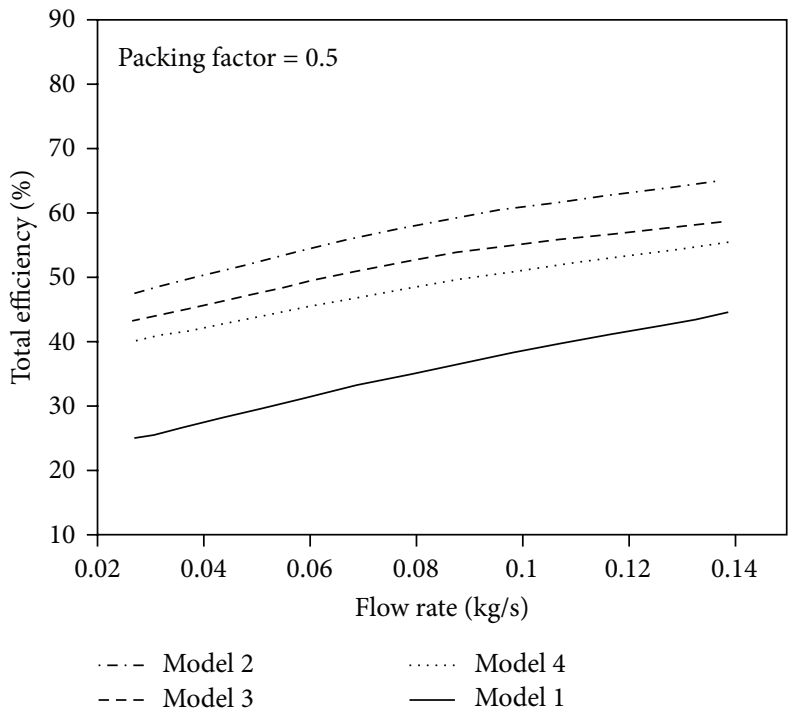

(c)

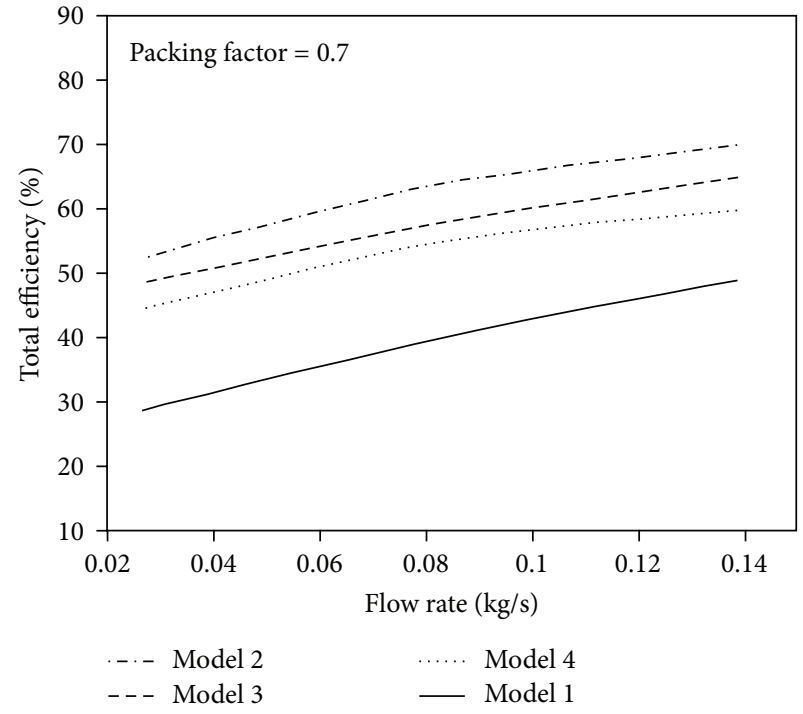

(b)

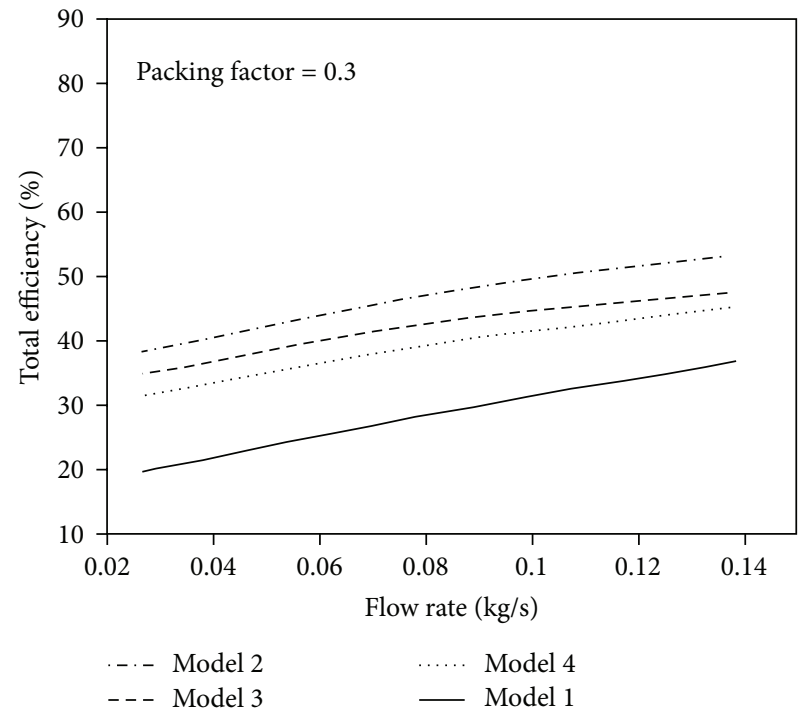

(d)

FIGURE 3: Total efficiencies of the four models at different packing factors.

TABLE 1: Comparison of energy and exergy efficiencies.

\begin{tabular}{lcc}
\hline Panel type & Energy efficiency & Exergy efficiency \\
\hline Unglazed PVT-air [36] & $45 \%$ & 10.75 \\
Single glazed PVT-air [37] & $55 \%$ & $13.5 \%$ \\
Single glazed PVT-air [38] & $55 \%-66 \%$ & $12 \%-15 \%$ \\
Double glazed T-air [39] & - & $7.4 \%$ \\
PVT-air [40] & $33 \%-45 \%$ & $11.3 \%-16 \%$ \\
PVT-water [41] & - & $3 \%-15 \%$ \\
\hline
\end{tabular}

PVT: photovoltaic thermal; T: thermal.

panel is significantly higher than its electrical energy output [42]. However, from the perspective of the second law of thermodynamics, thermal energy has a lower value compared with electrical energy.

Output exergy of a PVT panel is the sum of electrical and thermal exergies [43]:

$$
\mathrm{Ex}_{\mathrm{Out}}=\mathrm{Ex}_{\mathrm{El}}+\mathrm{Ex}_{\mathrm{Th}} \text {. }
$$

Electrical energy could be efficiently converted to work. Thus, electrical exergy is assumed to be equal to electrical energy [35]:

$$
\begin{gathered}
\mathrm{Ex}_{\mathrm{El}}=\mathrm{En}_{\mathrm{El}}, \\
\mathrm{En}_{\mathrm{El}}=\mathrm{En}_{\mathrm{PV}}=\eta_{\mathrm{PV}} \times A_{\mathrm{PV}} \times P \times S .
\end{gathered}
$$


Thermal exergy is defined as [44]

$$
\mathrm{Ex}_{\mathrm{Th}}=\dot{m} C_{p}\left[T_{2}-T_{1}-T_{a}\left(\ln \frac{T_{2}}{T_{1}}+\frac{\gamma-1}{\gamma} \ln \frac{P_{1}}{P_{2}}\right)\right],
$$

where $T_{a}$ denotes ambient temperature and $T_{1}, T_{2}, P_{1}$, and $P_{2}$ are the temperatures and pressures at the inlet and outlet of the PVT panel, respectively.

Exergy of solar radiation reaching the PVT panel is defined as [45]

$$
\mathrm{Ex}_{\text {Sun }}=S\left[1-\frac{4}{3}\left(\frac{T_{a}}{T_{\text {sun }}}\right)+\frac{1}{3}\left(\frac{T_{a}}{T_{\text {sun }}}\right)^{4}\right] .
$$

Exergy efficiency is defined as the output exergy (the sum of electrical and thermal output exergies) over the exergy of solar radiation $[36,44,46,47]$ :

$$
\eta_{\mathrm{Ex}}=\frac{\mathrm{Ex}_{\mathrm{Out}}}{\mathrm{Ex}_{\text {Sun }}}
$$

\section{Results and Discussion}

The mathematical model used in simulating the four panels at steady-state and daily climate of Malaysia is based on the first and second laws of thermodynamics.

3.1. Steady-State, First Law of Thermodynamics (Energy Balance Method). The total efficiency of each of the four model panels was calculated using (1) to (9) as shown in Figure 3. Additional glazing of Models 2, 3, and 4 reduces thermal loss and increases total efficiency. The effect of additional glazing is advantageous according to the first law of thermodynamics.

Increasing the air flow rate leads to increase of internal forced convection heat transfer coefficients according to (2). The higher heat transfer coefficient results in higher heat extraction rate, higher thermal efficiency, and lower panel operation temperature. The lower PVT panel operation temperature results in higher PV panel electrical efficiency (see (7)). The total efficiency of the panel is a function of thermal and electrical efficiencies (see (9)), which is expected to increase by increasing the air flow rate, as observed in Figure 3. The total efficiency of Model 4 was higher than that of Model 1 because it has a larger heat transfer surface. This finding is similar to the findings of earlier studies [19]. Model 2 has higher total efficiency rating than Model 4, which can be attributed to the lower temperature of air entering the channel beneath the PV lamination. Thermal efficiency increases with increasing air mass flow rate because of the increase in heat transfer coefficient, as reported by other researchers $[30,48,49]$.

3.2. Steady-State, Second Law of Thermodynamics (Exergy Method). Steady-state exergy was computed using (10) to (14). The exergy output of a PVT panel is the sum of thermal and electrical exergies (see (10)) [43]. The electrical exergy of a PVT panel is equal to its electrical energy, as confirmed by (11). Figure 4 shows the electrical exergy of the four models with a packing factor of 0.7 . All four models showed the same trend as Figure 4 for the packing factors $0.3,0.5$, and 1 .

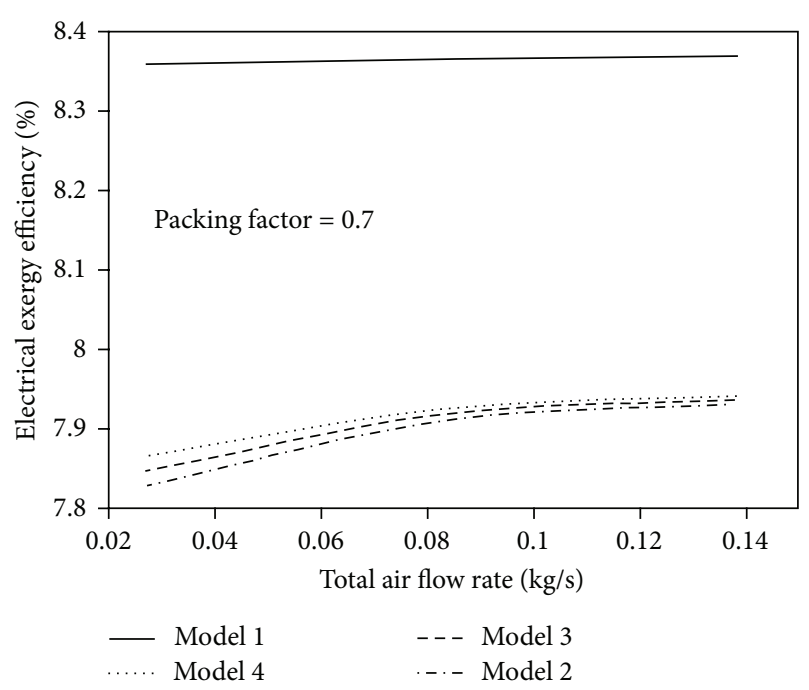

FIgURE 4: Electrical exergy of the four panel designs.

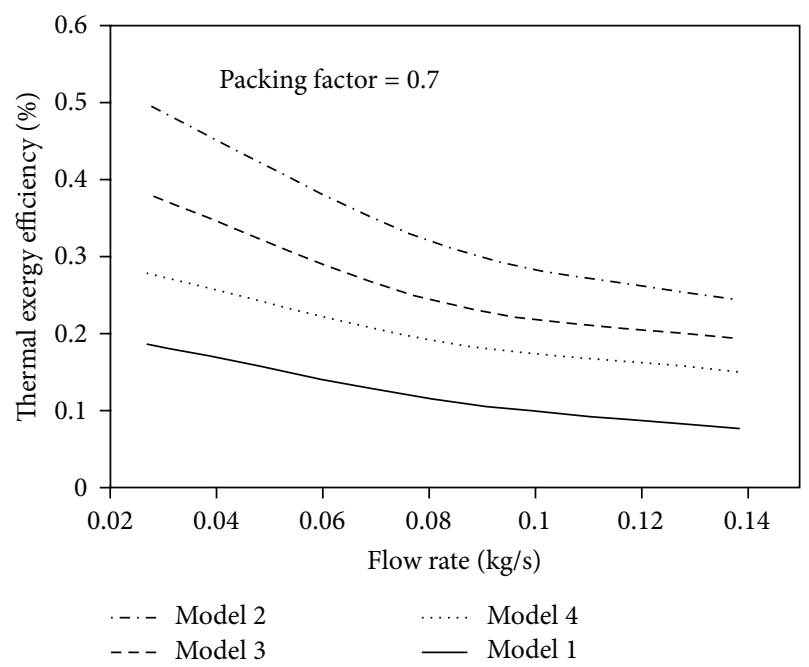

FIgURE 5: Thermal exergy efficiency of the four panel designs.

Models 2, 3, and 4 showed lower electrical exergies compared with Model 1 because of the reflection caused by additional glazing. Moreover, the white reflector only had $70 \%$ reflection performance, which affected the electrical exergy output of the rear surface of bifacial cells in all four models. Electrical exergy efficiency increases by increasing the air flow rate (Figure 4), which is attributed to higher heat extraction rate, lower PV panel temperature, and higher PV panel electrical efficiency consequently (see (7)). Model 1 is the most simple panel design among four models, which shows the best performance in terms of electrical output exergy.

Thermal exergy of all four models was calculated using (see (12)), as shown in Figure 5. All four models showed the same trend as Figure 5 for the packing factors $0.3,0.5,0.7$, and 1 . 


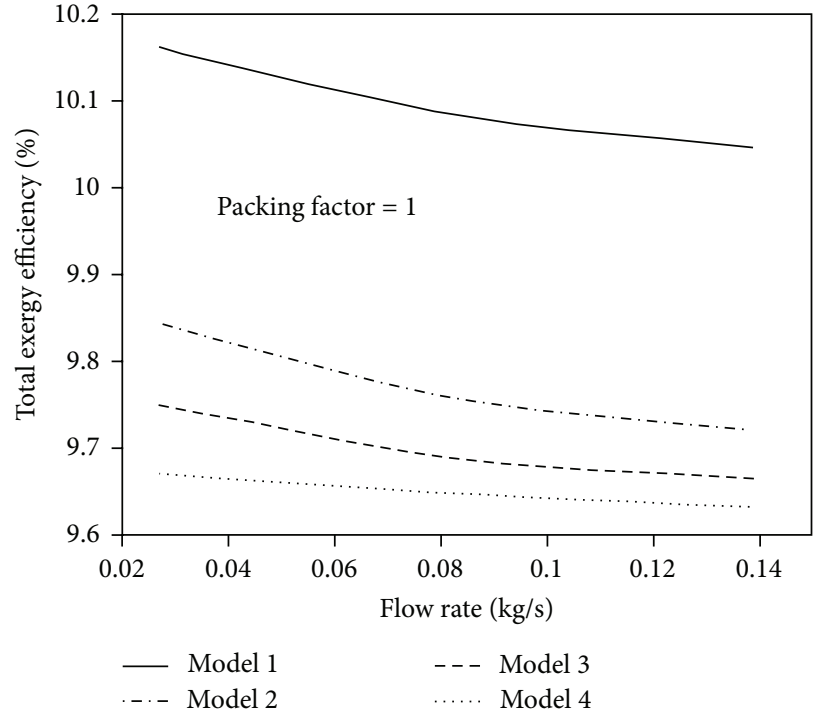

(a)

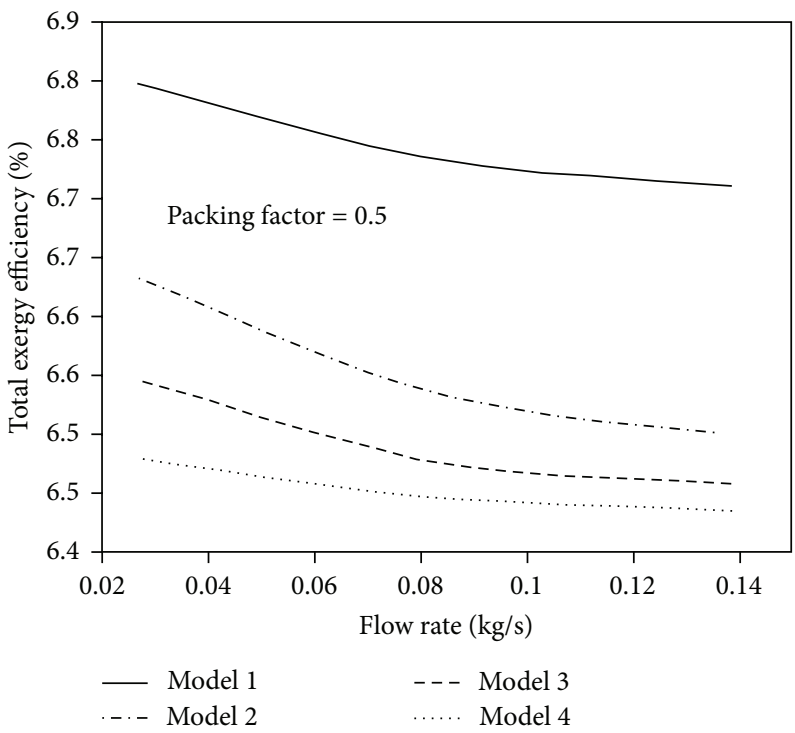

(c)

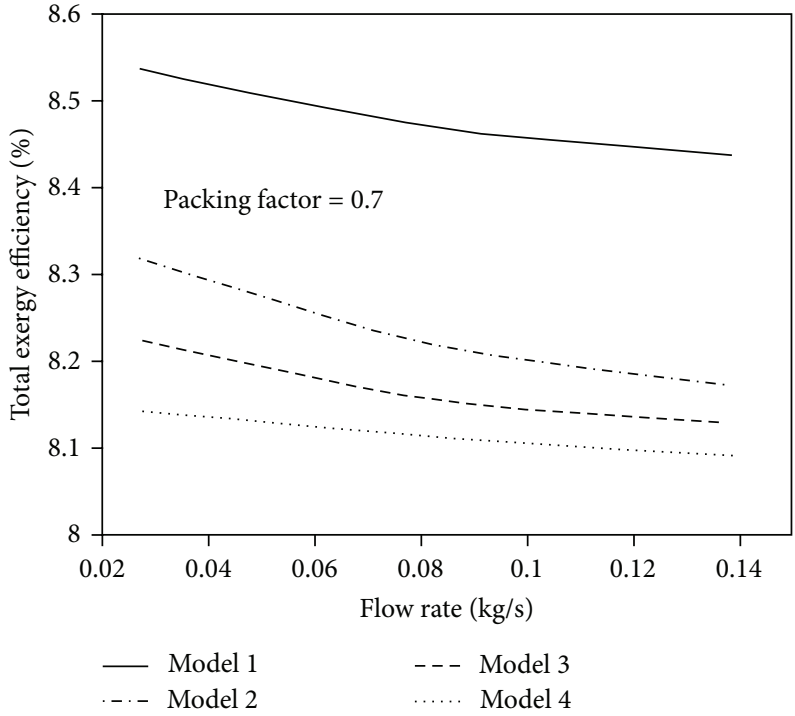

(b)

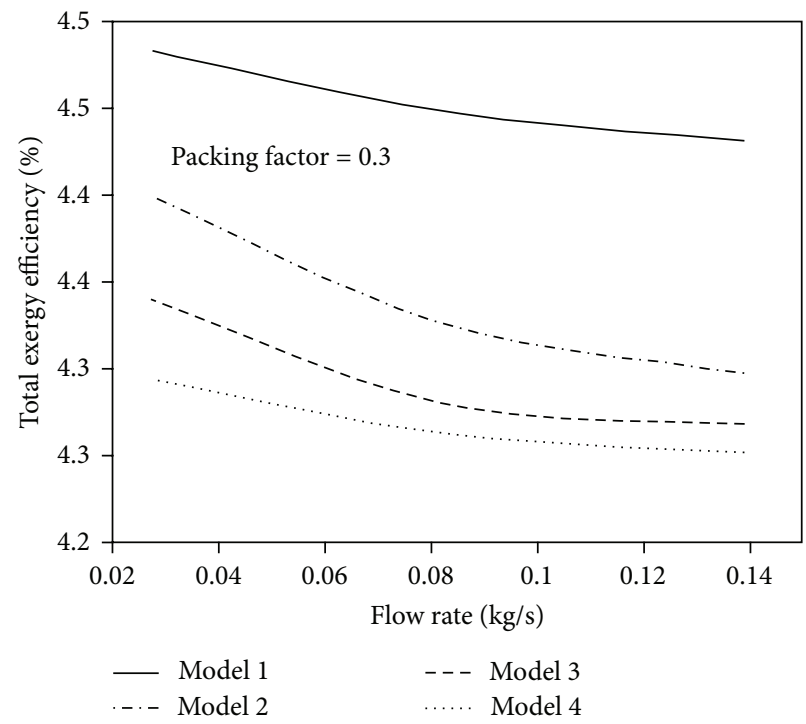

(d)

FIGURE 6: Total exergy efficiencies of the four models at different packing factors.

Increasing the air flow rate from $0.03 \mathrm{~kg} / \mathrm{s}$ to $0.14 \mathrm{~kg} / \mathrm{s} \mathrm{did}$ not significantly affect electrical exergy, as shown in Figure 4. However, according to Figure 5, a low flow rate is preferred in the case of all four models.

This observation is in accordance with the second law of thermodynamics and indicates that panels operate at low temperature that reduces the quality of output thermal power (exergy) with respect to the second law of thermodynamics (12). Models 2, 3, and 4 demonstrated higher thermal exergy at lower air flow rate, which has also been observed in earlier studies [25]. All four models show the same trend for thermal output exergy (Figure 5). Output exergy dropped with increasing air flow rate.

The exergy output of a PVT panel is the sum of thermal and electrical exergies (see (10)) [43]. Model 1 had a total exergy efficiency of $4.48 \%$ to $10.15 \%$, whereas its energy efficiency was $38 \%$ to $53 \%$ for packing factors 0.3 to 1 . Energy output of each of the four models increased with the air flow rate (Figure 3). However, the total exergy output of all four panels drops by increasing the air flow rate. The effect of air flow rate increase from $0.03 \mathrm{~kg} / \mathrm{s}$ to $0.14 \mathrm{~kg} / \mathrm{s}$ is less that $1 \%$. Electrical output exergy of the PVT panel is the dominant output exergy, which is not much depended on air flow rate (Figure 4).

Models 2, 3, and 4 had additional glazing that improved their thermal exergies. However, additional glazing has a negative effect on electrical exergy because of solar absorption and reflection as observed by previous authors [30]. Electrical exergy has higher contribution in total exergy output of a PVT panel compared with thermal exergy of a PVT panel; 


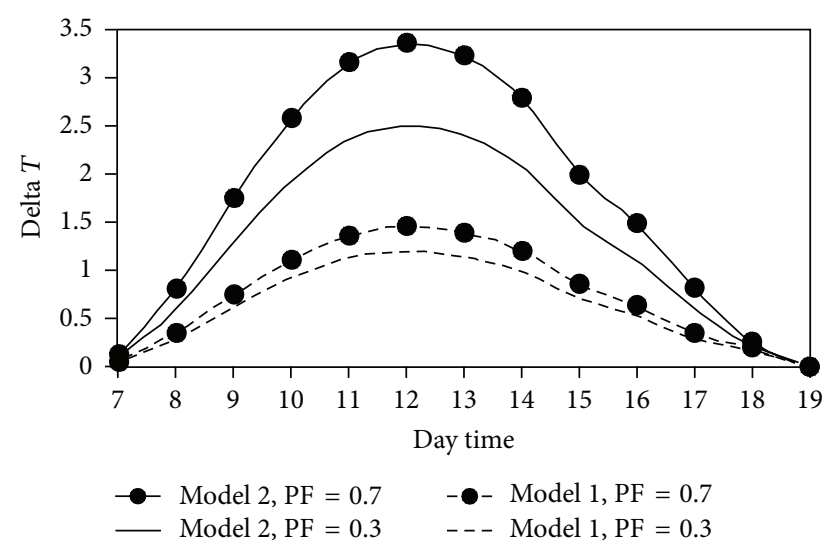

FIgURE 7: Air temperature increase in Models 1 and 2.

from the perspective of the second law of thermodynamics, a single-path bifacial PVT panel is preferable.

3.3. Daily Simulation. Monthly average, hourly solar radiation, and dry bulb temperature of Malaysia [50] were used to evaluate the bifacial PVT panels. Daily simulation was carried out by one-hour step time, whereby the temperatures of PV panel, reflector, and glazing at each step time were obtained and used as initial data for the next step.

As indicated by steady-state simulation, panel Models 2 and 1 were the best designs because of their performances as based on the first and second laws of thermodynamics, respectively.

Model 2 had the highest output energy (Figure 3), whereas, Model 1 had the highest output exergy (Figure 6). Therefore, Models 1 and 2 were selected for daily simulations. Figure 7 shows daily outlet air temperature increase for Models 1 and 2 at a flow rate of $0.08 \mathrm{~kg} / \mathrm{s}$ in a typical day in Malaysian climate. Output air temperature of Model 2 was higher than that of Model 1 (Figure 7).

Daily average energy and exergy efficiencies of Models 1 and 2 were calculated (Figure 8). Model 2 had the highest daily average energy efficiency among the four models, whereas Model 1 had the highest daily exergy efficiency. Daily average efficiency of Model 2 was 20\% higher than that of Model 1 at the same flow rate, but its exergy efficiency was only $0.35 \%$ lower than that of Model 1 . Model 2 is preferred for applications that demand high amount of low-grade energy (low-temperature thermal), whereas Model 1 is preferred for applications that require high-quality energy (electrical).

The exergy efficiencies of the panels were improved by increasing the packing factor from 0.3 to 0.7 . Meanwhile, the energy efficiencies showed less dependence on the packing factor. This contrast is because total exergy output is mainly dependent on electrical energy output (see (10) and (14)), whereas total energy output is mainly dependent on thermal energy output (see (9)).

\section{Conclusions}

Four air-based PVT panels were equipped with bifacial solar panel and were studied based on the first and second

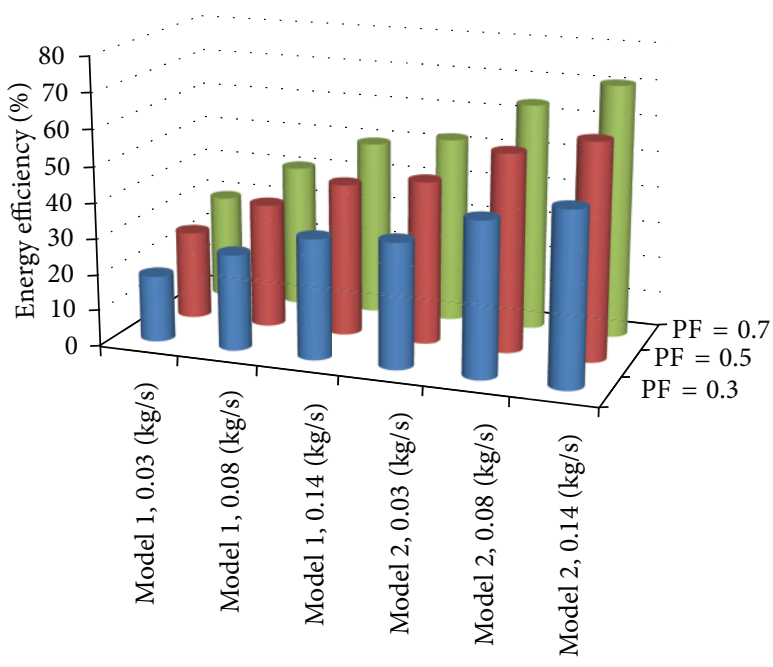

(a)

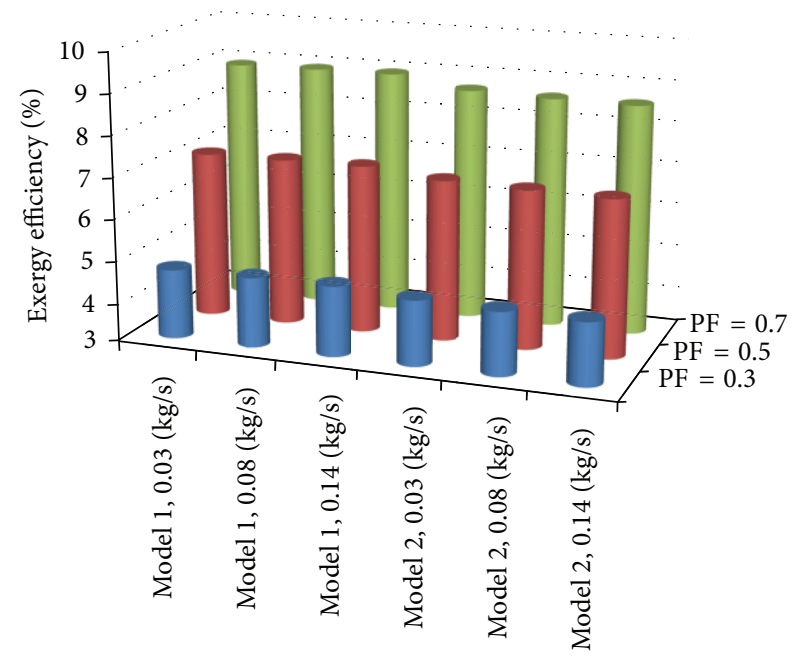

(b)

FIGURE 8: Daily average efficiencies of Models 1 and 2; (a) energy and (b) exergy.

laws of thermodynamics. Double-path-parallel panel had the highest total energy efficiency (35\% to 75\%), followed by double-path-counter flow panel, double-path-returning flow panel, and single-path panel. However, the single-path panel showed the highest exergy efficiency (4.48\% to $10.15 \%)$, followed by double-path-parallel panel, double-path-counter flow panel, and double-path-returning flow panel. Doublepath panels have an additional glazing that improved thermal energy and exergy efficiencies but have a negative effect on the electrical energy and exergy outputs. Single-path panel is the best option if electrical energy is the desired energy output of the panel, whereas double-path-parallel panel is recommended for maximum thermal energy output. Daily energy and exergy simulations were performed under the tropical climate of Malaysia. Double-path-parallel panel represented a daily average energy efficiency that was $20 \%$ higher than that of single-path panel. However, daily average exergy efficiency of double-path-parallel panel was only 
$0.35 \%$ lower than that of single-path panel at the same flow rate. PVT panels are mostly used for drying applications at tropical climate of Malaysia; the double-path-parallel panel is mostly recommended to maximize thermal energy harvest. The harvested electrical energy could be used to run electrical components of drying system such as air blowers and control system. High packing factor is preferable with regard to the first and second laws of thermodynamics. Economic analysis would be able to recommend the optimum packing factor.

\section{References}

[1] T. Uematsu, Y. Yazawa, K. Tsutsui et al., "Design and characterization of flat-plate static-concentrator photovoltaic modules," Solar Energy Materials and Solar Cells, vol. 67, no. 1-4, pp. 441448, 2001.

[2] A. Luque, A. Cuevas, and J. M. Ruiz, "Double-sided n+-p-n+ solar cell for bifacial concentration," Solar Cells, vol. 2, no. 2, pp. 151-166, 1980.

[3] A. Huebner, A. G. Aberle, and R. Hezel, “Temperature behavior of monofacial and bifacial silicon solar cells," in Proceedings of the 26th IEEE Photovoltaic Specialists Conference, pp. 223-226, October 1997.

[4] T. Joge, Y. Eguchi, Y. Imazu, I. Araki, T. Uematsu, and K. Matsukuma, "Applications and field tests of bifacial solar modules," in Proceedings of the 29th IEEE Photovoltaic Specialists Conference, pp. 1549-1552, May 2002.

[5] A. Moehlecke, I. Zanesco, A. C. Pan, T. C. Severo, and A. P. Mallmann, "Photovoltaic module with coloured diffuse reflectors," in Proceedings of the European Photovoltaic Solar Energy Conference, pp. 785-787, Munich, Germany, 2001.

[6] L. Yang, Q. H. Ye, A. Ebong et al., "High efficiency screen printed bifacial solar cells on monocrystalline CZ silicon," Progress in Photovoltaics, vol. 19, no. 3, pp. 275-279, 2011.

[7] P. Ooshaksaraei, K. Sopian, R. Zulkifli, M. A. Alghoul, and S. H. Zaidi, "Characterization of a bifacial photovoltaic panel integrated with external diffuse and semimirror type reflectors," International Journal of Photoenergy, vol. 2013, Article ID 465837, 7 pages, 2013.

[8] C. Duran, H. Deuser, R. Harney, and T. Buck, "Approaches to an improved IV and QE characterization of bifacial silicon solar cells and the prediction of their module performance," Energy Procedia, vol. 8, pp. 88-93, 2011.

[9] P. Ooshaksaraei, R. Zulkifli, S. H. Zaidi, M. A. Alghoul, A. Zaharim, and K. Sopian, "Terrestrial applications of bifacial photovoltaic solar panels," in Proceedings of the 10th International Conference on System Science and Simulation in Engineering, pp. 128-131, World Scientific and Engineering Academy and Society (WSEAS), Penang, Malaysia, 2011.

[10] M. L. Vladislav Poulek and I. Persic, "Bifacial tracking concentrator TRAXLE 5X," in Proceedings of the 2nd International Workshop on Concentraing Photovoltaic Powerplant: Optical Design and Grid Conection, 2009.

[11] B. Robles-Ocampo, E. Ruíz-Vasquez, H. Canseco-Sánchez et al., "Photovoltaic/thermal solar hybrid system with bifacial PV module and transparent plane collector," Solar Energy Materials and Solar Cells, vol. 91, no. 20, pp. 1966-1971, 2007.

[12] M. Brogren and B. Karlsson, "Low-concentrating water-cooled PV-thermal hybrid systems for high latitudes," in Proceedings of the 29th IEEE Photovoltaic Specialists Conference, pp. 1733-1736, May 2002.
[13] U. Ortabasi, K. Firor, and M. Ilyin, "Low concentration photovoltaic module design using bifacial solar cells," in Proceedings of the 20th IEEE Photovoltaic Specialists Conference, pp. 13241326, September 1988.

[14] U. Ortabasi, "Performance of a $2 \mathrm{X}$ cusp concentrator PV module using bifacial solar cells," in Proceedings of the 26th IEEE Conference Record of the Photovoltaic Specialists Conference (PVSC '97), Anaheim, Calif, USA, September 1997.

[15] K. J. Weber, V. Everett, P. N. K. Deenapanray, E. Franklin, and A. W. Blakers, "Modeling of static concentrator modules incorporating lambertian or v-groove rear reflectors," Solar Energy Materials and Solar Cells, vol. 90, no. 12, pp. 1741-1749, 2006.

[16] R. Hezel, "Novel applications of bifacial solar cells," Progress in Photovoltaics, vol. 11, no. 8, pp. 549-556, 2003.

[17] S. Yoon, S. Tak, J. Kim, Y. Jun, K. Kang, and J. Park, "Application of transparent dye-sensitized solar cells to building integrated photovoltaic systems," Building and Environment, vol. 46, no. 10, pp. 1899-1904, 2011.

[18] T. Y. Y. Fung and H. Yang, "Study on thermal performance of semi-transparent building-integrated photovoltaic glazings," Energy and Buildings, vol. 40, no. 3, pp. 341-350, 2008.

[19] K. Sopian, K. S. Yigit, H. T. Liu, S. Kakaç, and T. N. Veziroglu, "Performance analysis of photovoltaic thermal air heaters," Energy Conversion and Management, vol. 37, no. 11, pp. 16571670, 1996.

[20] B. Robles-Ocampo, E. Ruíz-Vasquez, H. Canseco-Sánchez et al., "Photovoltaic/thermal solar hybrid system with bifacial PV module and transparent plane collector," Solar Energy Materials and Solar Cells, vol. 91, no. 20, pp. 1966-1971, 2007.

[21] T. T. Chow, "A review on photovoltaic/thermal hybrid solar technology," Applied Energy, vol. 87, no. 2, pp. 365-379, 2010.

[22] R. Kumar and M. A. Rosen, "A critical review of photovoltaicthermal solar collectors for air heating," Applied Energy, vol. 88, no. 11, pp. 3603-3614, 2011.

[23] M. A. Hasan and K. Sumathy, "Photovoltaic thermal module concepts and their performance analysis: a review," Renewable and Sustainable Energy Reviews, vol. 14, no. 7, pp. 1845-1859, 2010.

[24] X. Zhang, X. Zhao, S. Smith, J. Xu, and X. Yu, "Review of $\mathrm{R} \& \mathrm{D}$ progress and practical application of the solar photovoltaic/thermal (PV/T) technologies," Renewable and Sustainable Energy Reviews, vol. 16, no. 1, pp. 599-617, 2012.

[25] D. Kamthania, S. Nayak, and G. N. Tiwari, "Performance evaluation of a hybrid photovoltaic thermal double pass facade for space heating," Energy and Buildings, vol. 43, no. 9, pp. 22742281, 2011.

[26] K. E. Park, G. H. Kang, H. I. Kim, G. J. Yu, and J. T. Kim, "Analysis of thermal and electrical performance of semitransparent photovoltaic (PV) module," Energy, vol. 35, no. 6, pp. 2681-2687, 2010.

[27] J. A. Duffie and W. A. Beckman, Solar Engineering of Thermal Processes, John Wiley \& Sons, 2nd edition, 1980.

[28] F. P. Incropera, D. P. DeWitt, T. L. Bergman, and A. S. Lavine, Fundamentals of Heat and Mass Transfer, John Wiley \& Sons, 6th edition, 1994.

[29] H. M. Tan and W. W. S. Charters, "Effect of thermal entrance region on turbulent forced-convective heat transfer for an asymmetrically heated rectangular duct with uniform heat flux," Solar Energy, vol. 12, no. 4, pp. 513-516, 1969. 
[30] A. Shahsavar and M. Ameri, "Experimental investigation and modeling of a direct-coupled PV/T air collector," Solar Energy, vol. 84, no. 11, pp. 1938-1958, 2010.

[31] D. L. Evans, "Simplified method for predicting photovoltaic array output," Solar Energy, vol. 27, no. 6, pp. 555-560, 1981.

[32] F. Sarhaddi, S. Farahat, H. Ajam, A. Behzadmehr, and M. Mahdavi Adeli, "An improved thermal and electrical model for a solar photovoltaic thermal (PV/T) air collector," Applied Energy, vol. 87, no. 7, pp. 2328-2339, 2010.

[33] J. Ji, J.-P. Lu, T.-T. Chow, W. He, and G. Pei, "A sensitivity study of a hybrid photovoltaic/thermal water-heating system with natural circulation," Applied Energy, vol. 84, no. 2, pp. 222-237, 2007.

[34] A. Bejan, G. Tsatsaronis, and M. Moran, Thermal Design and Optimization, John Wiley \& Sons, 1996.

[35] T. T. Chow, G. Pei, K. F. Fong, Z. Lin, A. L. S. Chan, and J. Ji, "Energy and exergy analysis of photovoltaic-thermal collector with and without glass cover," Applied Energy, vol. 86, no. 3, pp. 310-316, 2009.

[36] F. Sarhaddi, S. Farahat, H. Ajam, and A. Behzadmehr, "Exergetic performance assessment of a solar photovoltaic thermal (PV/T) air collector," Energy and Buildings, vol. 42, no. 11, pp. 2184-2199, 2010.

[37] M. Bosanac, B. Sorensen, I. Katic, H. Sorensen, B. Nielsen, and J. Badran, Photovoltaic/Thermal Solar Collectors and Their Potential in Denmark, EFP, 2003.

[38] A. S. Joshi and A. Tiwari, "Energy and exergy efficiencies of a hybrid photovoltaic-thermal (PV/T) air collector," Renewable Energy, vol. 32, no. 13, pp. 2223-2241, 2007.

[39] H. Ajam, S. Farahat, and F. Sarhaddi, "Exergetic optimization of solar air heaters and comparison with energy analysis," International Journal of Thermodynamics, vol. 8, no. 4, pp. 183190, 2005.

[40] A. S. Joshi, I. Dincer, and B. V. Reddy, "Thermodynamic assessment of photovoltaic systems," Solar Energy, vol. 83, no. 8, pp. 1139-1149, 2009.

[41] S. Kumar, G. Singh, G. N. Tiwari, and J. K. Yadav, "Thermal modelling of a hybrid photovoltaic thermal water heater in parallel configuration," International Journal of Sustainable Energy, vol. 35, no. 5, pp. 277-295, 2013.

[42] D. Ibrahim and S. J. Anand, "Solar PV and PV/T Systems," in Encyclopedia of Energy EngIneerIng and Technology, pp. 1-26, Taylor \& Francis, 2008.

[43] T. Fujisawa and T. Tani, "Annual exergy evaluation on photovoltaic-thermal hybrid collector," Solar Energy Materials and Solar Cells, vol. 47, no. 1-4, pp. 135-148, 1997.

[44] L. Borel and D. Favrat, Thermodynamics and Energy Systems Analysis from Energy to Exergy, CRC Press, 2010.

[45] R. Petela, "Exergy of undiluted thermal radiation," Solar Energy, vol. 74, no. 6, pp. 469-488, 2003.

[46] A. Hepbasli, "A key review on exergetic analysis and assessment of renewable energy resources for a sustainable future," Renewable and Sustainable Energy Reviews, vol. 12, no. 3, pp. 593-661, 2008.

[47] S. Nayak and G. N. Tiwari, "Energy and exergy analysis of photovoltaic/thermal integrated with a solar greenhouse," Energy and Buildings, vol. 40, no. 11, pp. 2015-2021, 2008.

[48] K. Sopian, H. T. Liu, S. Kakac, and T. N. Veziroglu, "Performance of a double pass photovoltaic thermal solar collector suitable for solar drying systems," Energy Conversion and Management, vol. 41, no. 4, pp. 353-365, 2000.
[49] J. K. Tonui and Y. Tripanagnostopoulos, "Air-cooled PV/T solar collectors with low cost performance improvements," Solar Energy, vol. 81, no. 4, pp. 498-511, 2007.

[50] M. Z. Hussin, M. H. A. Hamid, Z. M. Zain, and R. A. Rahman, "An evaluation data of solar irradiation and dry bulb temperature at Subang under Malaysian climate," in Proceedings of the IEEE Control and System Graduate Research Colloquium (ICSGRC '10), pp. 55-60, June 2010. 

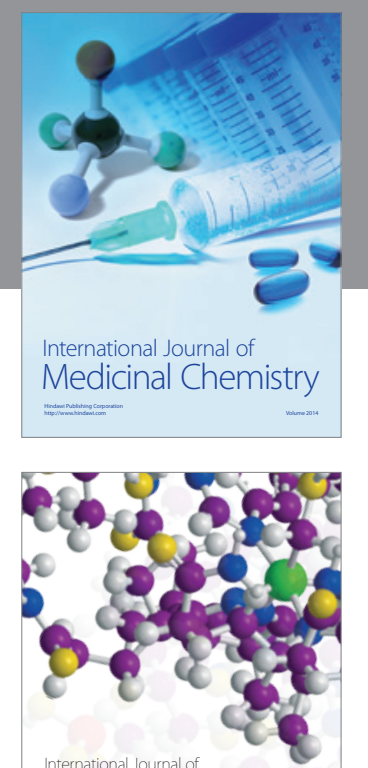

\section{Carbohydrate} Chemistry

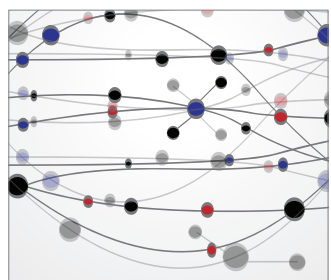

The Scientific World Journal
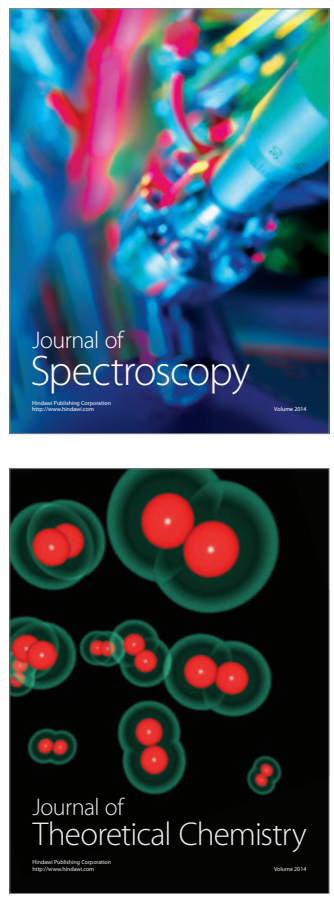
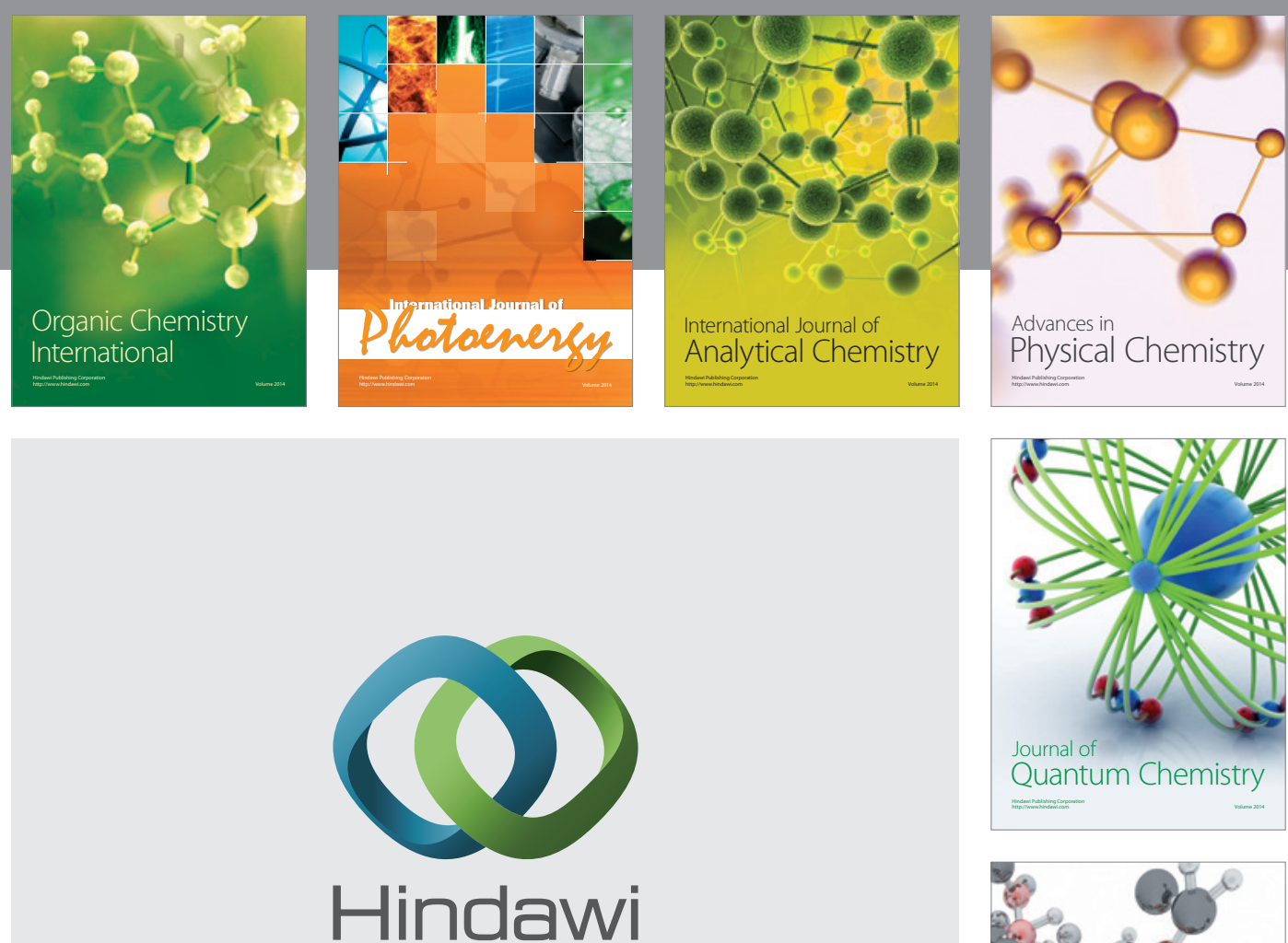

Submit your manuscripts at

http://www.hindawi.com

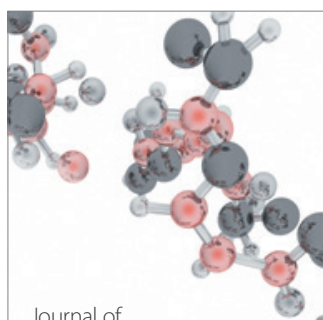

Analytical Methods

in Chemistry

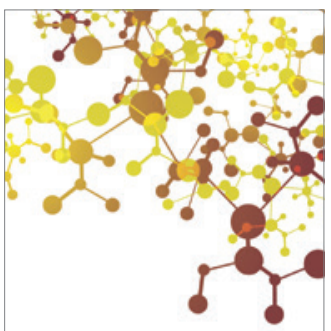

Journal of

Applied Chemistry

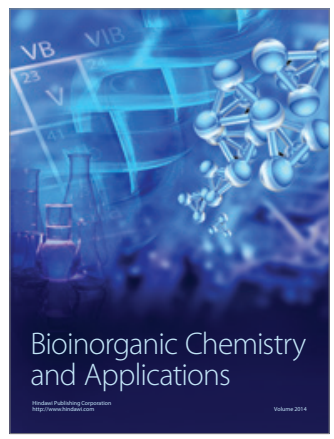

Inorganic Chemistry
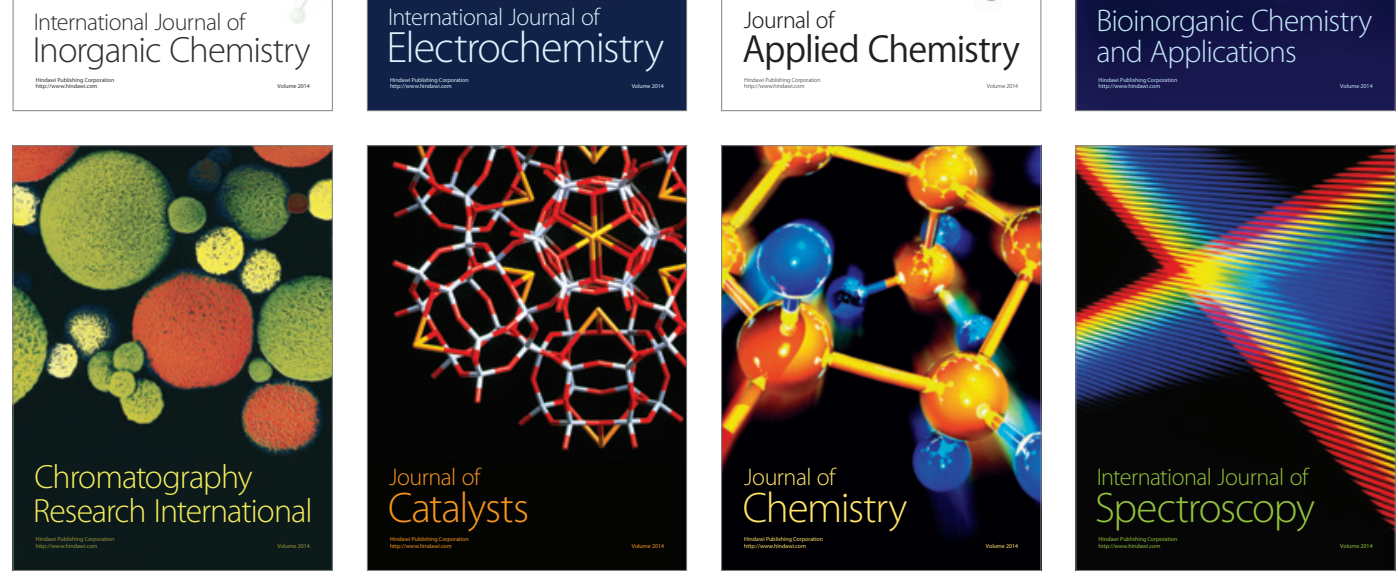